THE TYNDALE BIBLICAL ARCHAEOLOGY LECTURE, 1979*

\title{
TEMPLES OF THE LEVANT AND THE BUILDINGS OF SOLOMON
}

By Christopher J. Davey

The Books of the Kings leave even the casual reader with the definite impression that the material culture of ancient Israel climaxed during the reign of King solomon. /1/ While the buildings for which he was responsible are described in some detail emphasizing their lavishness, subsequent kings are reported to have looted them during times of economic stress and there is little mention of any further building./2/ Yet despite the detail of chapters 6 and 7 of 1 Kings, the modern reader can hardly be expected to visualize Solomon's buildings with any accuracy. The opulence of the temple and surrounding palaces is manifest, but the architectural details are sometimes omitted, and where they are mentioned there are numerous obscurities. Some of this mystery can be removed by carefully studying the Hebrew text with reference to architectural descriptions found in other ancient Semitic languages. Another source of clarification has been sought in the analysis of contemporary buildings unearthed by archaeologists; it is this second field of examination that is to be developed in this paper./3/

*Delivered at Tyndale House, Cambridge in July 1979. In presenting this paper here, the author gratefully acknowledges the encouragement of the Tyndale Fellowship members, and in particular of Alan Millard who made many helpful comments.

1. In purely archaeological terms, as far as Jerusalem is concerned, this at present is not the case; $K$. Kenyon, The Bible and Recent Archaeology (London: British Museum, 1978) 52.

2. $2 \mathrm{Ki}$. 18:16 records the removal by Hezekiah of gold overlay which he himself had applied to the temple. $2 \mathrm{Ki}$. 22:3-7 describes repairs made during the reign of King Josiah. See the forthcoming study by A. R. Millard, King Solomon's Gold.

3. Examples of this approach can be seen in S. M. Paul \& W. G. Dever, Biblical Archaeology (Jerusalem: Keter, 
Ancient temples provide, at present, the richest comparative material for this investigation and so the less numerous and more complex palaces of the Levant will not be considered./4/ It is hoped that this study will not only increase an architectural appreciation of Solomon's buildings, but will also afford an indication of the cultural continuum to which his work belonged.

Before concentrating on archaeological remains it is well to clarify some of the issues raised by the biblical descriptions of Solomon's buildings which are found in the Books of the Kings, in 2 Chronicles chapters 3 and 4, and also in Ezekiel's description (chapters 41-42) of a future temple/5/ which is no doubt partly dependent on the building of solomon known to him./6/

The main part of Solomon's temple is called הבית 'the House' and is sixty cubits long, twenty cubits wide and thirty cubits high (MT, I Ki. 6:2; 2 Ch. 3:3; LXX: twentyfive cubits high). While J. Fergusson envisages columns supporting the roof of 'the House',/7/ most scholars believe it to have been roofed by a single span as this was perfectly feasible. The דביר (debir $)$ or holy of holies however is not so free of controversy. This room

3. Contd.

1973) 74 and R. de Vaux, Ancient Israel, Its Life and Institutions (London: Darton, Longman \& Todd, 1973) 313.

4. Such palaces have been found at Ras Shamra, Alalakh and Megiddo from the Late Bronze Age and at Zinjirli, Hazor, Hama and Megiddo from the Iron Age.

5. The merits and otherwise of this type of eclectic approach are discussed by Jean Ouellette, 'The basic structure of Solomon's Temple and Archaeological Research', in The Temple of Solomon, ed. J. Gutmann (Missoula: Scholars Press, 1976) 1-3.

6. G. A. Cooke, The Book of Ezekiel (ICC. Edinburgh: Clark, 1951) 425. The temple of Ezekiel's age, however, had undergone at least one renovation or reconstruction; cf. $2 \mathrm{Ki}$. 22:3-7.

7. The Temples of the Jews and the other buildings of the Haram: Area (London: John Murray, 1878) 26-39, figs. 4 \& 5. Fergusson believed that both the temple and tabernacle had gable roofs on the assumption that a single span would sag. $1 \mathrm{Ki} .10: 12$ and 2. Ki. 18: 16 were cited as support for a columned structure. 
was situated at the rear of 'the House' (1 Ki. 6:16). It had the shape of a cube of twenty cubits (1 Ki. 6:20; 2 Ch. 3:8; Ez. 41:4) so that it occupied the entire width of 'the House' and left an area forty cubits long in front of it ( $1 \mathrm{Ki} .6: 17$; Ez. 41:2) which became the main room or היכל (hêkāl). Vincent suggested a reconstruction of the temple in which the debir was a separate architectural unit isolated from the hêkāl by a thick masonry wall and having its own roof./8/ A wooden partition is implied by the or text (1 Ki. 6:16) and as its slenderness would correspond with the given dimensions, most scholars now seem to accept it as a more probable construction./9/ The height of the debir was ten cubits less than the hêkăl and so it has been suggested that, as in Egyptian temples, the roof height of the temple progressively decreased toward the rear of the building./10/ Alternatively it has been conjectured that the debir was situated on a platform and was approached by a flight of stairs./11/ Another theory is that the upper chambers (תול (ת) referred to in 2 Chronicles 3:9 may have been constructed in the space between the roofs of the hêkāl and the debîr./12/ Th. A. Busink, however, is content to locate the $d e_{b i r}$ on the same floor as the hêkāl and to leave the space above it unoccupied./13/

8. L. H. Vincent, Jérusalem de I'Ancien Testament II-III (Paris: Le coffre, 1956) 373-431, pl. 51.

9. J. Ouellette, 'The Solomonic $D^{\text {ebir }}$ according to the Hebrew Text of 1 Kings 6', JBL 89 (1970) 339-341; R. de Vaux, op. cit. 314; Th. A. Busink, Der Tempel von Jerusalem (Leiden: E. J. Brill, 1970) 208.

10. L. H. Vincent, op. cit., fig. 112; J. B. Pelt, Histoire de I'Ancien Testament II (1930) 26.

11. K. Galling, 'Das Allerheiligste in Salomos Tempel', JPOS 12 (1932) 43-48; also in Biblische Reallexikon (Tübingen, 1937) 516; P. L. Garber, 'Reconstructing Solomon's Temple', BA 14 (1951) 2-24; R. de Vaux, op. cit. 314; A. Parrot, The Temple of Jerusalem (London: SCM, 1957) 54.

12. C. Watzinger, Denkmäler Palästinas 1 (Leipzig: J. C. Hinrichs, 1933) 88, fig. 1.6; but the meaning of the Hebrew is uncertain.

13. Op. cit. 197-209, fig. 49, 56. 
In front of the hêkāl was a porch (אולם) which was as broad as the temple (1 Ki. 6:3; $2 \mathrm{Ch} .3: 4 ; \mathrm{Ez} .41: 2$ ) and ten cubits deep (1 Ki. 6:3). The Chronicler states that the porch was one hundred and twenty cubits high ( $2 \mathrm{Ch}$. 3:4), which is approximately equivalent to a fifteen storey building and is entirely unrealistic. In fact a recent reconstruction by Th. A. Busink depicts the porch roof lower than that of the main building./14/ The resulting facade is not very impressive. Wright and Albright on the other hand saw no reason to make the porch different in height to the hêkal./15/ Numerous other scholars have added flanking towers to the porch to improve what would otherwise be a very plain facade, /16/ while one scholar has suggested a facade not unlike a nineteenth century German castle./17/ By extending the side chambers to the front of the porch and adding slightly to their height, $C$. Watzinger produced a simple but imposing facade similar to that of Egyptian temples whose entrances were flanked by pylons./18/

Discussion of the temple entrance has sometimes centred upon a comparison with bīt hilāni palaces./19/ While the bīt hilāni itself is an architectural element belonging to a palace and beyond the scope of this paper, the validity of such a comparison can certainly be questioned here. The traditional bīt hilāni often had the throne

14. Op. cit., fig. 52 .

15. G. E. Wright, 'The Stevens' Reconstruction of the Solomonic Temple', BA 18 (1955) 41-44.

16. J. Fergusson, op. cit. 26-39; J. B. Pelt, op. cit. 26;

L. H. Vincent, op. cit., pl. 5l, fig. 112 .

17. C. Schick, Die Stiftshütte, der Tempel in Jerusalem und der Tempelplatz der Jetztzeit (Berlin: 1896) 60, fig. 29.

18. op. cit. 88.

19. J. Ouellette, op. cit. 8-11, and in 'Le Vestibule du Temple de Salomon était-il un Bit Hilani?', $R B 76$ (1969) 365-378. H. Frankfort, The Art and Architecture of the Ancient Orient (London: Penguin, 1954) 167, describes a bỉt hilāni as follows: 'One enters a portico with one to three columns which gives access to the throne room. Both portico and throne room have their main axis parallel to the facade. stairs to the upper storey are set to one side of the portico.' 
room doorway offset from the main axis/20/ and had an open front, whereas the porch of solomon's temple had its doorway arranged on a straight axis and the vestibule was probably partially enclosed, so that the designs, and no doubt the functions also, of these architectural components were basically different. The two pillars, Yachin and Boaz, at the entrance of Solomon's temple are sometimes considered to be similar to the bīt hilāni entrance columns./21/ However a glance at the palaces of zinjirli reveals that there can be one to three columns incorporated in a bit hiläni and therefore there appears to be a different meaning in these architectural constituents./22/ The bit hilani columns were essentially structural in purpose while Yachin and Boaz appear to have been of religious significance. This is to some extent amplified by archaeological evidence which testifies to many earlier temples with pairs of column bases outside their entrances./23/ This evidence, together with the fact that Yachin and Boaz are listed with the temple furnishings, makes it reasonable to conclude, for the present, that parallels for the entrance of Solomon's temple are not primarily to be found in contemporary palace architecture./24/ The issue however is by no means closed.

20. Most bīt hilani palaces are known from their foundations only and the exact locations of the doorways are not clear. Hilāni $\mathrm{K}$ at Zinjirli definitely had an off-centre doorway. F. von Luschen, Ausgrabungen in Sendschirli (Berlin: Reimer, 1911) 290-301, pl. 49. Another hilāni, at Carchemish, was however symmetrical: L. Woolley, Carchemìsh III (London: British Museum, 1952) 176-184, pls. 38-40.

21. J. Ouellette in The Temple of Solomon, ed. J. Gutmann (Missoula: Scholars Press, 1976) 11.

22. F. Von Luschen, op. cit., fig. 175.

23. Such temples as Hazor Area $\mathrm{H}$ (Y. Yadin, Hazor (Iondon: OUP, 1972) 89); Kition Temple of Astarte, Area 2 Temple 1 (V. Karageorghis, Kition (London: Thames and Hudson, 1976) 98); Shechem Migdol (G. E. Wright, Shechem (London: Duckworth, 1965) 82ff); and Arad ( $Y$. Aharoni, 'Arad: Its Inscriptions and Temple', $B A 31$ (1968)). The entrance columns of the temple of Tell Tacyinat were almost certainly structural components however.

24. Th. A. Busink, op. cit. 572. It is possible that the listing with the temple furnishings may have been simply because the bronze from which they were constructed was booty. 
The biblical description of Solomon's temple mentions structures generally referred to as 'side rooms' ( $1 \mathrm{Ki}$. 6:5-10). This term is used to translate two Hebrew words, ע the text. However, it is not clear whether these terms do in fact refer to the same structure or whether one is a component of the other, or whether they are quite different. The structures are not mentioned in Chronicles and only צלעות are referred to by Ezekiel (Ez. 40:6-11).

Despite considerable conjecture/25/ most scholars reconstruct the temple with a series of three storeys of side rooms built around the hêkāl and the debir (1 Ki. 6:5) although $C$. Watzinger extends them to the front of the temple./26/ There is also a general consensus that the temple was constructed on a platform and approached by a flight of stairs./27/

The other buildings referred to in 1 kings include the House of the Forest of Lebanon $(7: 2-5)$, and the Porch of Pillars $(7: 6)$, the Porch of the Throne $(7: 7)$ and the palace $(7: 8)$. The House of the Forest of Lebanon is the only building to receive more than a passing reference. It was one hundred cubits long and fifty cubits wide and was thirty cubits high $(7: 2)$. The MT states that there were four rows of columns with fifteen in a row, while the LXX indicates that there were only three rows. I. H. Vincent accepted the MT/28/ while Th. A. Busink has adopted the LXX./29/

25. For a variety of theories see: $R$. de Vaux, op. cit. 315; K. Galling, Biblische Reallexikon, 517; $\mathrm{K}$. Möhlenbrink, Der Tempel Von Solomos (Stuttgart: Israelitische-Jüdische Abteilung, 1932) 146; J. Gray, $I$ and II Kings (London: SCM, 1963) 155; L. Waterman, JNES 2 (1943) 286; J. Ouellette, JNES 31 (1972) 188189; D. W. Gooding, VT 17 (1967) 144; Th. Friedrich, Tempel und Palast Solomos (Innsbruck, 1887).

26. Op. cit. 88 .

27. For discussions see Th. Busink, op. cit. 171; L. Waterman, IoC. cit. 286; P. I. Garber, BA 14 (1951) 67; A. Parrot, op. cit. 25; S. M. Paul and W. G. Dever, op. cit. 78, 79.

28. Op. cit. 424, fig. 133.

29. Op. cit. 135, fig. 37 . 
Columned halls have been found at Boghazkoy,/30/ Altin Tepe/31/ and El-Amarna/32/ and are well known from the Persian period at Persepolis,/33/ but until recently no Phoenician parallels have been found.

\section{TEMPIES OF THE ILEVANT}

The Levantine temples which have at one time or another been compared with the architecture and design of Solomon's temple will be considered in the categories to which they belong./34/

Three Room Buildings (Fig. 1)

Megiddo, Stratum VIIA Area AA, Early Iron Age. G. Loud, Megiddo II (O.I.P. 42. Chicago, 1948) 3137, fig. 384 .

Hama, Stratum E Building IV, Iron Age. E. Fugman, Hama II.1 (Copenhagen: Wendt and Jensen, 1958) 234, fig. 308 .

Neither of these buildings can be conclusively identified as a temple.

Building IV of the Iron Age II stratum at Hama was bereft of sacred artefacts. It was constructed during the ninth or tenth centuries BC and was probably looted and destroyed by Sargon II in 720 BC. The excavators believed that the structure was the southern tower of a gate although there were no remains of the northern tower and no evidence of an adjacent major wall. As no temple was found associated with the neighbouring palace it is possible that this structure was the royal chapel.

30. K. Bittel, Boğazköy III (Berlin: Mann, 1957) 10-17, figs. $4,5$.

31. T. Özgüç, Altin Tepe (Ankara: Türk Tarih Kurumu Basimevi, 1966) 44-46, pls. 5, 6, 18, 19.

32. J. D. S. Pendlebury, The City of Akhenaten III (London: OUP, 1951) 87, pl. 16.

33. S. A. Matheson, Persia, an Archaeological Guide (London: Faber, 1972) fig. 32.

34. A fuller classification of temples is to be published by the author in a future volume of $P E Q$. 

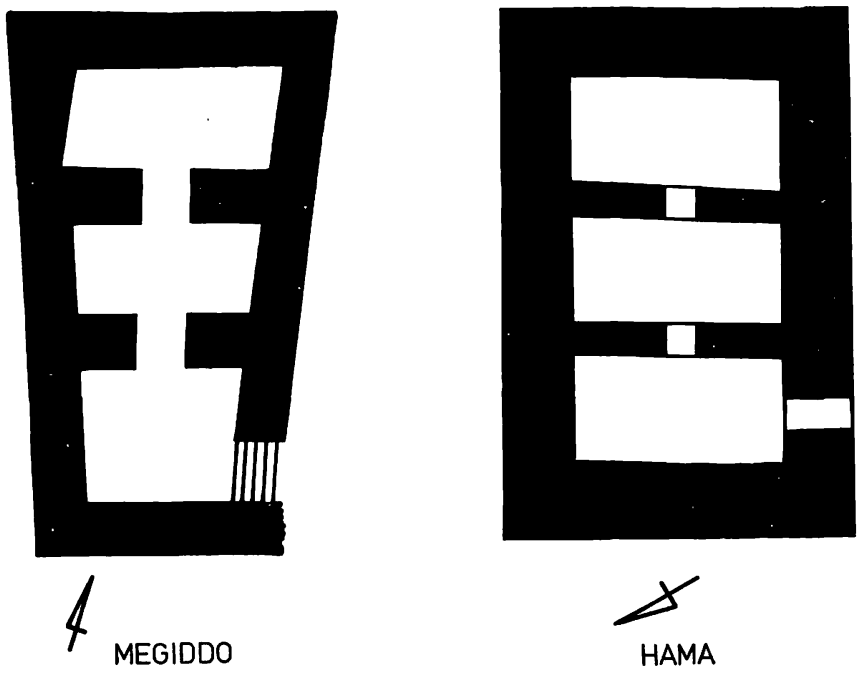

0 10

FIG. 1 Three Room Buildings

The Megiddo structure was a basement associated with the Early Iron Age palace and as it appeared to be a strong building and fragments of ivory and jewellery were found in it, the excavators identified it as a treasury. Franken has suggested, however, that it may have been a temple or private shrine./35/ It is significant that it was situated within an area occupied by an earlier building included in the list of Levantine Broadroom temples and a later building which also may have been a temple./36/

While these two buildings may have-been temples, they are not quite as easily compared with the temple of solomon as Ussishkin has suggested./37/ The Megiddo building is

35. H. J. Franken and C. A. Franken-Battershill, A Primer of old Testament Archaeology (Leiden: E. J. Brill, 1963) 63.

36. See below, pages 122, 124, 144-146.

37. D. Ussishkin, 'Building IV in Hamath and the Temples of Solomon and Tell Tayanat', IEJ 16 (1966) 104-110. 
aligned approximately north-south as all known temples at Megiddo were. Ussishkin sees significance in the east-west alignment of the Hama building, but the fact that it faced west destroys any parallel in this respect with the temple of solomon. A comparison of the rooms reveals that the dimensions and proportions of the middle rooms were totally different to the equivalent room in Solomon's temple, the hêkāl, and it is therefore most probable that their functions were also dissimilar. Contrary to the excavators, Ussishkin places the entrance of the Hama building in the centre of the western wall/38/ thus increasing its affinity with the temple of Solomon. However there is no reason not to follow the excavators who located the entrance on the southern side producing, although they were unaware of it at the time, a configuration of doorways identical to that of the Megiddo building.

The Hama E building IV and the Megiddo Stratum VII structure were of almost identical design and while it is possible that they were temples, it must be concluded that they had very little resemblance to the temple of solomon.

\section{Broadroom Temples (Fig. 2)}

Et Tell, Early Bronze Age. J. Marquet-Krause, Les Fouilles de'Ay (Paris: Geuthner, 1949); J. Callaway, 'The $1964 \mathrm{Ai}$ (Et Tell) Excavattons', BASOR 178 (1965) 31-39.

Megiddo, Stratum XIX, Early Bronze Age. G. Ioud, Megiddo II (O.I.P. 42, Chicago, 1948) Fig. 143. Kition, Phoenician, Iron Age. V. Karageorghis, Kition (Iondon: Thames and Hudson, 1976) chapter 5.

Arad, Early Iron Age. Y. Aharoni, 'Arad: Its Inscriptions and Temple', BA 31 (1968) 1-32.

These temples were true Broadrooms in that their main rooms had width to length ratios of at least three to one.

The Et Tell building was originally excavated by $\mathrm{J}$. Marquet-Krause in 1934 who identified it as a palace, but subsequent field investigations by Prof. J. Callaway seem

38. Ibid. fig. 3 . 


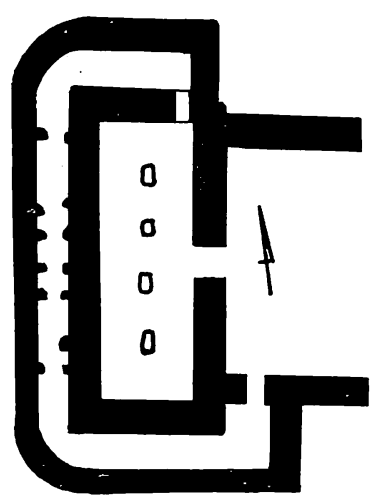

ET-TELL
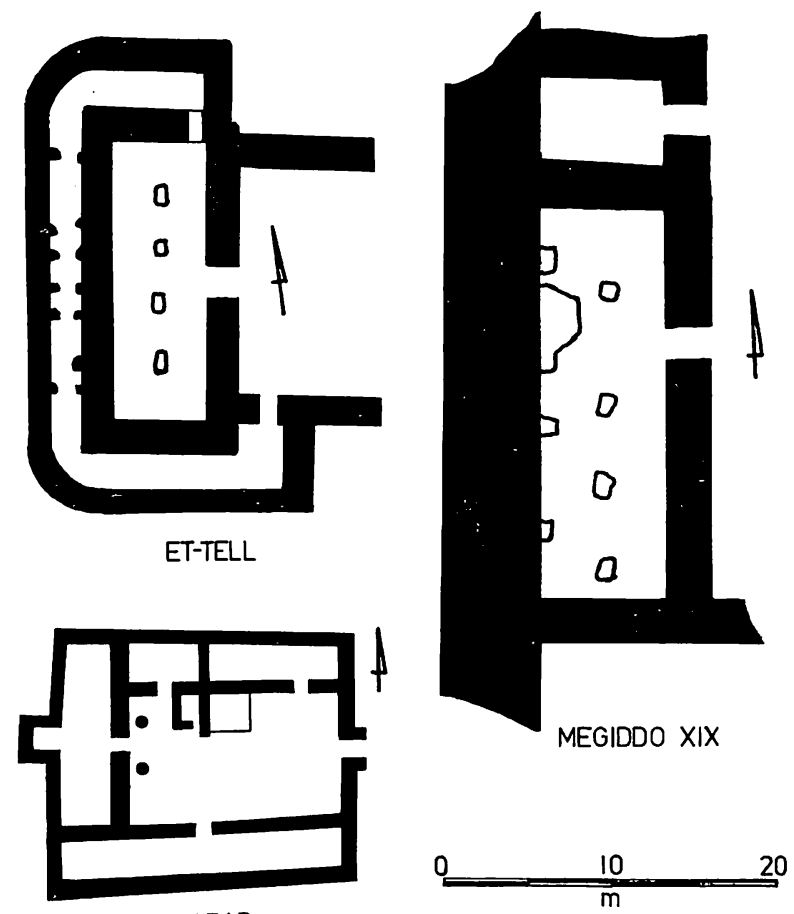

T.ARAD

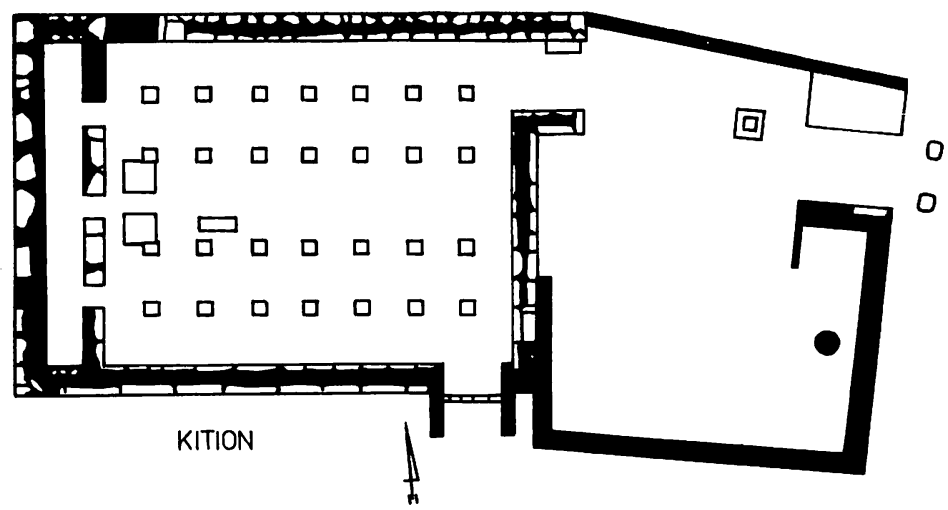

FIG. 2 Broadroom Temples 
to have necessitated a reinterpretation./39/ There is little difficulty in reconstructing Marquet-Krause's palace as a Broadroom temple similar to a contemporary Early Bronze Age temple in Stratum XIX at Megiddo. These temples seem to testify to a tradition of Broadroom temples in Early Bronze Age Palestine. This tradition is not discernible in the Middle Bronze Age and Wright's suggestion that the Early Bronze Age Broadroom temples develop into the temple tradition that will later be called the Levantine Broadroom may be true./40/

There can be no suggestion that the Early Bronze Age temples of Palestine and the later Broadroom temples at Arad and Kition form a coherent tradition although it must be noted that all of them have the same eastward orientation. However the later buildings are themselves of considerable interest. While Kition, Cyprus, is not in the Levant, a building recently excavated there cannot be ignored by this study. It was constructed by colonists from the Levant, the Phoenicians, who were intimately associated with the erection of Solomon's temple. The temple was dedicated to Astarte and in plan at least has a remarkable resemblance to the third century BC temple of Aphrodite at Paphos, depicted on a Roman coin,/41/ but there is clearly no similarity to the temple of solomon.

The Kition temple was an important ninth century BC Phoenician temple and is the only definite major Phoenician religious building known at present./42/

39. G. E. Wright, 'The Significance of $A i$ in the third millennium BC', Archäeologie und Altes Testament (Galling Festschrift. Tübingen: Mohr, 1970) 307.

40. Ibid. 312 .

41. V. Karageorghis, op. cit., pl. 71.

42. Two small phoenician temples have been excavated. One was a second smaller temple in the sacred area at Kition, room 36, ibid., figs. 18, 19; and the other a small building at Sarepta: J. B. Pritchard, Sarepta (Philadelphia: University Museum, 1975) 13-15, fig. 2. Both have a long room plan but with the entrance placed near one corner on the shorter side. The design principle is that of a Bent-axis temple, a plan which the Sarepta temple had for at least one building phase. The benches around the Sarepta temple lead Pritchard to group the temple with other small Canaanite temples. 
While the design of the temple may have been partly determined by earlier sanctuaries built on the same site, the Rition temple was still a Phoenician temple and it is therefore now Impossible to argue that Solomon's temple had a Phoentcian design simply on the basis of the nationality of the contracted workforce./43/ Before such a hypothesis can be adopted, clear evidence from the Phoenician homeland will have to be forthcoming.

The significance of the temple of Astarte in relation to Solomon's buildings is in its comparison with the 'House of the Forest of Iebanon'. The columned hall of the temple is slightly narrower than the 'Bouse of the Forest of Lebanon' and exactly half its length. Its roof was supported upon columns which were positioned in four rows and had precisely the same longitudinal spacing as described by the MT. Scholars have sometimes rejected the MT description of the 'Bouse of the Forest of Lebanon on the practical grounds that the number of columns involved was unrealistically high,/44/ but as we now have a contemporary Phoenician building with almost identical column design specifications, the objection is no longer valid. In addition this may be viewed as a testimony to the accuracy of the detail of the ancient scribes' description.

The Hebrew ostraca found in the vicinity of the sacred building discovered at Tell Arad seemed to indicate that it was an Israelite structure. While there were no flgurines amongst the'remains, a stone pillar and two incense altars were unearthed in the so-called holy of holies, testifying to the religious nature of the building. This was reinforced by the discovery of two

43. As for example: C. Watzinger, op. cit. 89; W. F. Albright, From Stone Age to Christianity (Baltimore: Johns Hopkins, 1957) 294; S. M. Paul and W. G. Dever, op. cit. 75; K. Kenyon, Archaeology in the Holy Land (London: Benn, 4th ed., 1979) 243.

44. J. L. Myers, 'King Solomon's Temple and other Buildings', PEQ (1948) 33. 
column bases flanking the entrance of the main room and a 2.5 metre square courtyard altar which was used during at least one phase of the temple.

While this building was possibly constructed during the reign of King Solomon, it bears little resemblance to the Jerusalem temple./45/ This may be partially explained by the fact that the Tell Arad building was no more than a provincial shrine,/46/ although it does also seem to provide evidence for the existence of a rival tradition of temple design in ancient Israel.

Aharoni argued that the Arad temple was based largely on the design of the tabernacle, the description of which he believed was modified under the influence of Solomon's temple./47/ This theory, however, fails to explain the origin of the niche which is the focal point of the Tell Arad sanctuary. Nor does it explain the columns which appear to have stood at the entrance and the benches which surround the main room. These features would appear to place the Tell Arad temple in quite a different religious tradition, whatever dimensional coincidences there were between the two Israelite temples.

Levantine Broadroom Temples (Figs. 3 \& 4)

Megiddo, Stratum XV, E.B.-M.B.. G. Loud, Megiddo II (O.I.P. 42. Chicago, 1948) 78-87, fig. 180.

45. Initially Aharoni argued for a close correlation with the temple of Solomon, 'The Negeb', Archaeology and old Testament Study, ed. D. Winton Thomas (Oxford: Clarendon, 1961) 395, but later, in 'The Solomonic Temple, the Tabernacle and the Arad Sanctuary', Ancient Orient and occident (1973) 4, Aharoni stated otherwise.

46. It is recognized that such an explanation poses complex problems of the relationship between temple design, religious belief, liturgical practice and political pressure.

47. Ibid. 4. 


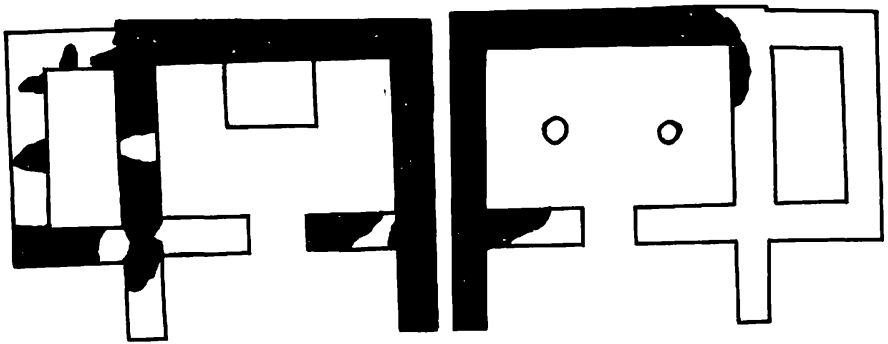

1 MEgIDDO XV
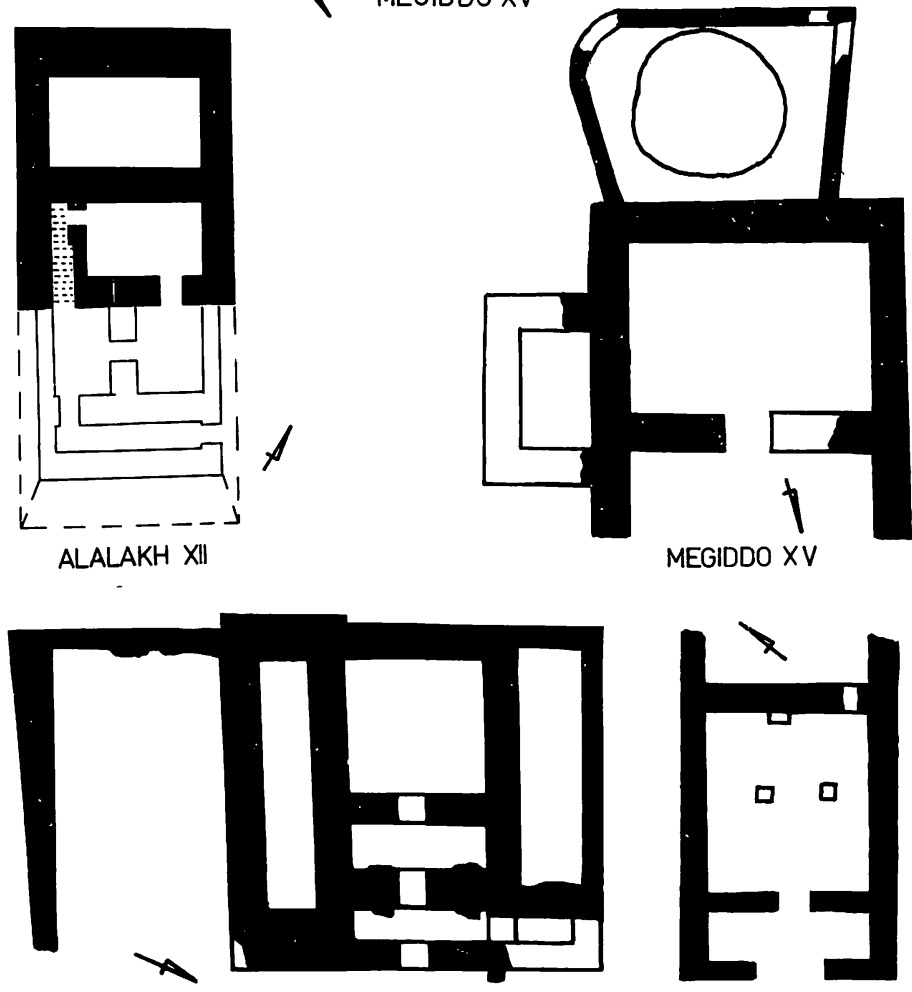

BYBLOS

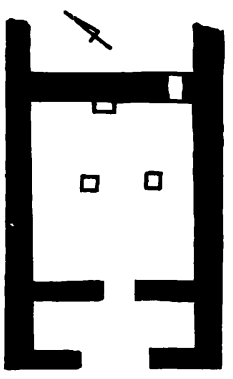

SHECHEM

FIG. 3

Levantine Broadroom Temples I 
DAVEY: Temples of the Levant

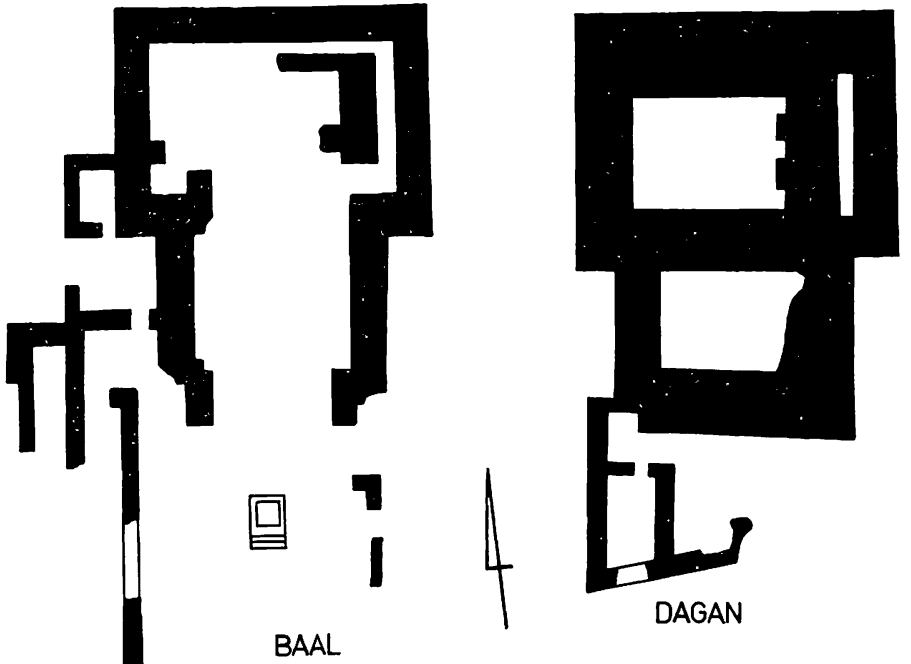

RAS SHAMRA

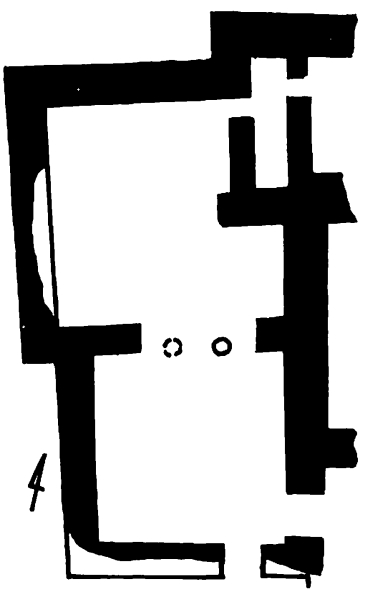

MEGIDDO VIII

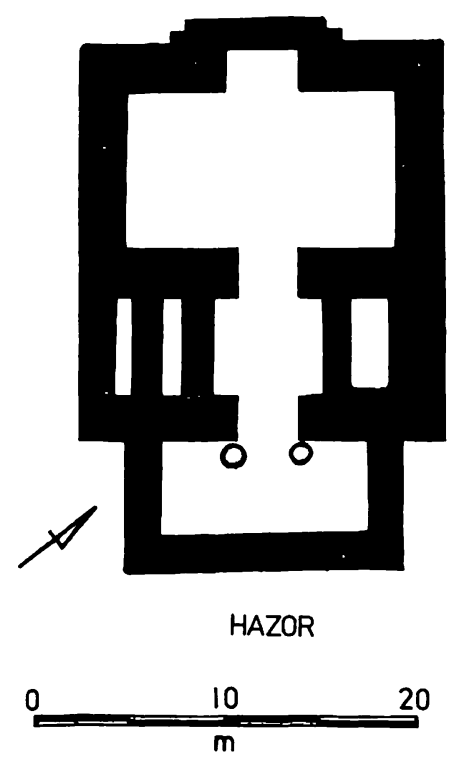

FIG. 4 Levantine Broadroom Temples II 
Ras Shamra, Temple of Baal, M.B.-L.B.. C.F.A. Schaeffer, The Cuneiform Texts of Ras Shamra (London: OUP, 1939) pl. 39.

Ras Shamra, Temple of Dagan, M.B.-L.B.. C. F. A. Schaeffer, ibid. pl. 39.

Shechem, Building 7300, M.B.. Notes and News, IEJ 23 (1973) 243, fig. 1.

Hazor, Area H, M.B.-L.B.. Y. Yadin, Hazor (London: OUP, 1972) 75-95, fig. 20.

Alalakh, Level XII, M.B.. L. Woolley, Alalakh (Oxford: University Press, 1955) 71-73, fig. 30. Byblos, Bâtiment II, M.B.. M. Dunand, Fouilles de Byblos 1 (Paris: Geuthner, 1939) 296-299, fig. 248.

Megiddo, Area AA Stratum VIII, L.B.. G. Loud, Megiddo II (O.I.P. 42. Chicago, 1948) 25, fig. 382 .

This category has been designated the Levantine Broadroom temple/48/ to distinguish it from the traditional Broadroom temple which had rooms of quite different proportions./49/ Broadroom temples are well attested in southern Mesopotamia where they had wide cellas with little depth, so that the deity's image which was located immediately opposite the entrance was well lit and could easily be observed from the outside. However, as this group of Levantine temples had cellas which were almost square and also possessed anterooms and porches, it is unlikely that anything of the cella's interior could have been viewed from without. The religious characteristics of the Levantine Broadroom temples are therefore quite different from the traditional Broadroom temple and should not be confused, especially as examples of the latter do occasionally occur in the Levant.

48. The name 'Canaanite temple' may also be appropriate, but would predetermine the ethnic and religious issues related to this architectural grouping.

49. G. R. H. Wright, 'Pre-Israelite Temples in the Land of Canaan', PEQ 19 (1971) 25. 
At first glance the orientation of the Levantine Broadroom temple seems to be quite random. Y. Yadin has suggested, however, that in fact one of the diagonals may be aligned with a point of the compass. $/ 50 /$ Wile it is possible to force almost any temple into one form of agreement or another with either magnetic or true north, the fact remains that one diagonal of the temples at Hazor, Megiddo Stratum XV, Shechem and Byblos is approximately east-west, one diagonal of the Alalakh temple is aligned north-south and the temples at Ras Shamra and Megiddo Area AA Stratum VIII face almost due south. The alignment of these temples is in most cases only known approximately and until excavators give details of their azimuth determination it will not be possible to ascertain whether or not this orientation is entirely coincidental. But even if it can be establishea that temple diagonals were deliberately aligned with points of the compass, there is still the difficulty of finding an explanation for this practice. For the moment it may be concluded that orientation was not an important or uniform feature of this temple type.

Most of the Levantine Broadroom temples were symmetrical in plan. The Level XII temple at Alalakh was an exception although most subsequent temples built on the same site were symmetrically designed. It is probable that the Alalakh level XII temple was an archaic form of this plan of temple./51/

Large stairways are a common feature in the Levantine Broadroom temples and where they are not evident it is possible that access may have been obtained either to the roof or to an upper room via an adjacent building. The Byblos temple, Bâtiment II, has been reconstructed with a

50. Op. cit. 104-105.

51. P. Matthiae, 'Unité et Développement du Temple dans la Syrie du Bronze Moyen', RAI 20 (1975) 47f. For the revised dating of the Alalakh Strata see $B$. Hrouda, Die bemalte Keramik des zweiten Jahrtausends in Nordmesopotamien und Nordsyrien (Berlin: Mann, 1957) $28-37$. 
plan independently deduced by Matthiae/52/ and Saghieh /53/ and it is possible that the corridor on the south side was a stairway similar to that found in the Alalakh Level IV temple./54/

The cultic character of the Megiddo Area AA Stratum VIII building is far from certain but as a neighbouring room, 2041, was probably a throne room, it is possible that the other two major rooms on the ground floor of the palace formed the chapel. Building 7300 at Shechem was possibly a palace chapel which had two column bases symmetrically arranged in the main room like many of the Levantine Broadroom temples.

At Hazor and Ras Shamra centrally sited courtyard altars were found and these together with the two column bases discovered at the entrance of the Hazor temple are reminiscent of features in Solomon's temple. The combination of the courtyard and temple building is highlighted by a Ugaritic text which describes the construction of the temple of Baal:-

Let a house be built for Baal like the gods', And a court like the Children of Asherah's./55/

The epic goes on to recount a dispute which arose over the intention of the builder, Kothar, to incorporate a window in the temple. Baal protests:

Let not Padriya the daughter of $\mathrm{Ar}$ be seen or Talliya daughter of Rabb be espied./56/

52. Loc. cit. 52, 53.

53. M. S. Saghieh, Byblos in the Third Millennium: $A$

Reconstruction of the Stratigraphy and a study of the Cultural Connections (PhD Thesis, University of London, 1975) pl. 17. Saghieh differs from Matthiae in that she suggests an open porch.

54. L. Woolley, Alalakh (Oxford: University Press, 1955) 71-73.

55. J. B. Pritchard, Ancient Near Eastern Texts

(Princeton: University Press, 1969) 133.

56. Ibid. 134. 
This appears to be a reference to a window made in the facade of the temple through which women could be observed maybe in a manner similar to that suggested by the 'woman at the window pose' well known from ivory relief plaques./57/ Baal eventually relents, although it seems that the windows which were incorporated in the building correspond to the lattices of heaven through which rain fell and may therefore have been situated in the temple roof and not in the facade./58/

The variations of wall thickness prompted Woolley to suggest that the main room of the Alalakh Level XII temple had greater height than the front room in a manner illustrated by a terra-cotta model building found at Selemiyah which is now in the Aleppo Museum./59/ Models of two stage buildings of this type have been found in religious contexts at locations as far apart as Assur and Beth Shan and it would seem that they represent a common style of temple./60/ quite independently schaeffer came to the same conclusion with regard to the two temples he excavated at Ras Shamra. While the parallel cited by him, an Egyptian Migdol Fortress of Seti I,/61/ seems far removed, Th. A. Busink endorses such a reconstruction./62/

The temples at Hazor/63/ and Alalakh/64/ are known to have had wooden beams incorporated in their mudbrick

57. For example J. B. Pritchard, The Ancient Near East in Pictures (Princeton: University Press, 1954) fig. 131.

58. C. F. A. Schaeffer, The Cuneiform texts of Ras Shamra (London: OUP, 1939) 67; W. F. Albright, Archaeology and the Religion of Israel (Baltimore: Johns Hopkins, 1956) 88 .

59. L. Woolley, op. cit., pl. 9b.

60. W. Andrae, Die Archäischen Ischtar-Tempel in Assur (DOG 39. Osnabrück: Otto Zeller, 1970) 35-38, pls. 1317; A. Rowe, The Four Canaanite Temples of Beth Shan (Philadelphia: University of Pennsylvania, 1940) 41$44,54-56$, figs. $7,37,38$, pls. 18, 57A.

61. C. F. A. Schaeffer, op. cit. 67, fig. 14.

62. Op. cit., fig. 134.

63. Y. Yadin, op. cit. 89.

64. I. Woolley, op. cit. 224, 225, fig. 71, pls. 13, 15, 17. 
walls and this has been thought similar to the construction of the great court, the inner court and the porch of the temple of Solomon ( $1 \mathrm{Ki} .6: 36 ; 7: 12$ )./65/ However it is clear from the design that beams were used in the lower portions of the walls at Alalakh as tie rods to give the tensile strength necessary for supporting a high wall./66/ Stone, on the other hand, can support its own weight so the cedar wood employed by Solomon as alternative coursing with 'hewn stone' was more likely used to give the walls the resilience to withstand earthquake, as bonding to compensate for inaccuracies in the stones' squareness and maybe to enhance the appearance. 167/ If it is correct to understand that the OT describes three to one alternate coursing of stone and wood, it is unlikely that contemporary parallels of this technique will be found as they would have been destroyed, the wood burnt or looted and the wall collapsed. Examples of Solomonic masonry which was both dressed and coursed can be found in the gates at Megiddo /68/ and Gezer./69/

During the earliest two phases the temple at Hazor had only a platform in front of it but in the Late Bronze Age

65. R. de Vaux, op. cit. 317; A. Parrot, The Temple of Jerusalem (London: SCM, 1957) 41; J. Garstang, The Heritage of Solomon (London: Williams and Norgate, 1934) 382.

66. That is, to stop the wall bulging under its own weight.

67. Most stone has sufficient strength to support its own weight. Further discussion of the use of mudbrick reinforced by wooden beams can be found in C. I. Woolley, Carchemish II (London: British Museum, 1969) 143-156, and R. C. Haines, Excavations in the Plain of Antioch II (OIP 95. Chicago, 1971) 45, 46, 53, 54, although these are not directly relevant to the wood and stone construction employed by Solomon.

68. G. Loud, Megiddo II (OIP 42. Chicago, 1948) 46-57. Cf. Y. Shiloh, Levant 12 (1980) 72 for wooden beams in the Megiddo gate and other buildings.

69. Y. Yadin, 'Solomon's City Wall and Gate at Gezer', IEJ 8 (1958) 81-86; K. Kenyon, The Bible and Recent Archaeology, fig. 66. 
II and III phases an enclosed porch was added. With this addition the temple comprised three roous situated one behind the other and aligned on a common axis. Initially Y. Yadin saw this tripartite structure as the antecedent of Solomon's temple which was also composed of three rooms adjoined in series./70/ This suggestion was also made by W. F. Albright/71/ and $A$. Parrot,/72/ and has been followed in numerous subsequent works which discuss Solomon's temple./73/ However, as Th. A. Busink has already demonstrated, the proportions of the rooms of the Area $\mathrm{H}$ temple at Hazor both collectively and individually bear no resemblance to those of Solomon's temple./74/ It follows that the function of each room in the two buildings was substantially different and that therefore they were essentially dissimilar structures. The presence of the staircase in the middle room and the type of furniture discovered in the cella of the Hazor temple accentuate the disparity between the two buildings. The Hazor temple was not always a free-standing structure and it conformed to all the Levantine Broadroom temples which were integral to their urban or political environment and in this respect they were entirely unlike the temple of Solomon.

Egyptian Influenced Broadroom Temples (Fig. 5)

Beth Shan, Stratum VII, I.B.. A. Rowe, The Four Canaanite Temples of Beth Shan (Philadelphia: University of Pennsylvania, 1940) 13-21, ch. 3, pl. 8 .

Lachish, L.B.. C. Clamer and D. Ussishkin, 'A Canaanite Temple at Tell Lachish', BA 40.2 (1977) 71-76.

Byblos, Obelisk Temple. M. Dunand, Fouilles de Byblos II (Paris: Maisonneuve, 1954) fig. 767.

70. 'Excavations at Hazor, 1958', IEJ 9 (1959) 81.

71. 'Dunand's New Byblos Volume: A Lycian at the Byblian Court', BASOR 155 (1959) 32.

72. Op. cit. 23 .

73. R. de Vaux, op. cit. 317; P. R. S. Moorey, Bible Lands (Oxford: Elsevir Phaidon, 1975) 38; J. Bright, A History of Israel (London: SCM, 1960) 196, n. 75.

74. Op. cit. 591-592. 


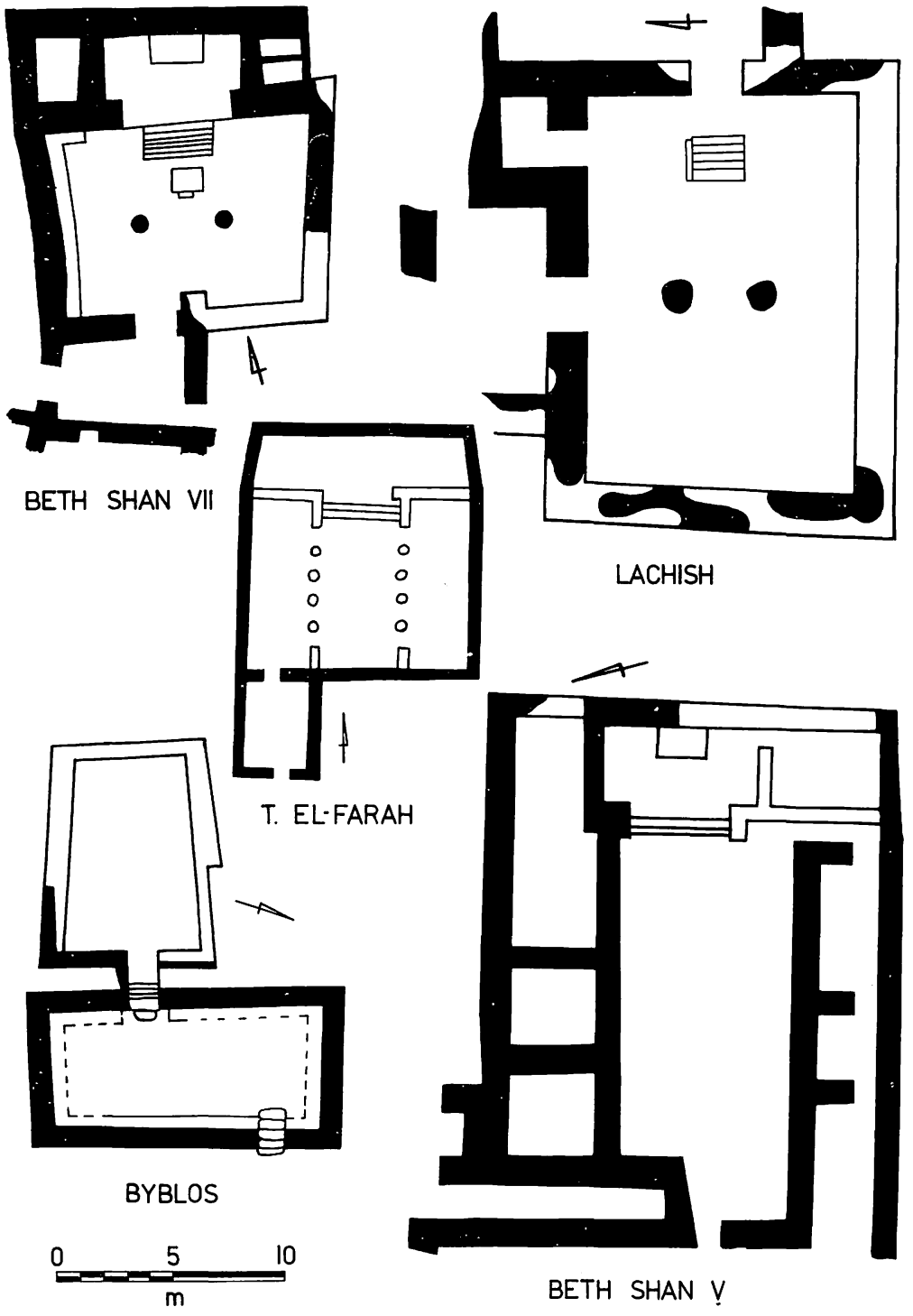

FIG. 5 Egyptian Influenced Broadroom Temples 
Beth Shan, Southern Temple Stratum V, Iron Age. A. Rowe, The Four Canaanite Temples of Beth Shan (Philadelphia: University of Pennsylvania, 1940) 22-30, ch. 4, pl. 10.

Tell el Farah, Iron Age. R. de Vaux, 'Les Fouilles de Tell el-Farah près Naplouse', RB 64 (1957) 575, fig. 8 .

These buildings form a sub-group of the Levantine Broadroom temples and are primarily distinguished by the large number of Egyptian artefacts and architectural elements found amongst their ruins. Architecturally the main departure from the Levantine Broadroom is the isolation of the cella from the main room so that it is a separate entity approached by a flight of stairs. These temples do not have their entrances arranged on a central axis as do most Levantine Broadroom temples, and in fact it appears that their doorways were deliberately offset so that the cella could not be observed from outside the main room. The cella is in most cases further isolated from the world by the addition of an entrance room. In accord with the Levantine Broadroom temples, the Egyptian influenced temples were not autonomous structures and instead were an element in much larger cultic complexes.

While the plan of the Beth Shan temple, Stratum VII, is quite dissimilar to the traditional Egyptian temple, the excavators have suggested that the mortuary chapels at El-Amarna were direct parallels. A couple of the chapels, nos. 525 and 535, had elevated cellas, benches around the main room and off-set entrances although they were considerably smaller than the Beth Shan temple./75/ Whatever relationship there was between El-Amarna and Beth Shan, the major design principle of Egyptian temples was the isolation of the naos or shrine from the remainder of the temple and indeed from the world,/76/

75. T. E. Peet and C. L. Woolley, The City of Akhenaten Pt. 1 (Iondon: EES, 1923) pls. 24-26. R. Giveon, 'Egyptian Temples in Canaan', Museum Haaretz Bulletin 14 (1972) 51, suggested that the El-Amarna mortuary chapels may have originally been a Canaanite design.

76. H. H. Nelson, 'The Egyptian Temple', BA 7 (1944) 41 and in BA Reader $I$ (Missoula: Scholars Press, 1975) 147 . 
and it is this principle which seems to have provided the impetus for the modification of the traditional

Levantine Broadroom temple. Egyptian temples from the Middle and New Kingdom excavated at Ezbet Rushdi,/77/ Medinet Madi,/78/ and Mit Rahineh/79/ all have cellas separated from the main hall of the temple although in each case it appears that a triad of gods were worshipped.

Recent excavations at Lachish uncovered a contemporary temple which was similar in size and shape to the Beth Shan temple. This discovery seems to establish beyond doubt that the Beth Shan temple does represent a definite temple class of its own. Two column bases were found in the Lachish temple together with some fragments of charred cedar beams revealing that the main hall was probably roofed - unlike the main area of the El Amarna mortuary chapels. A large stone threshhold was found on the northern side of the temple fixing the location of the entrance to the main room.

A second preliminary report on the Lachish temple notes the similarity with the Beth Shar temple and states that the temple antechamber was on the west side of the building and not on the north./80/ This is an open question as the western antechamber floor is lower than the temple main room and there is no evidence of an interconnecting stairway or doorway. Nor is the plan of the antechamber known. It is quite unnecessary for Ussishkin to attempt to restore the temple to a symmetric plan because it appears to be uncharacteristic of this class of temple. His suggestion that this building was built according to the plan which later served as a prototype for Solomon's architects/81/ is entirely unrealistic. The religious and architectural principles of the Levantine Broadroom temples of which the Lachish temple is a hybrid form are quite the opposite of those which characterized Solomon's temple.

77. Shehata Adam, Annales du Service des Antiquités de I'Egypte 56 (1959) 205-226, pls. 2, 3.

78. J. Vandier, Manuel d'Archéologie Egyptienne II (Paris: Picard, 1955) 619-620, fig. 326.

79. R. Anthes, Mit Rahineh 1955 (Philadelphia: The University Museum, 1959) pls. 1, 2.

80. D. Ussishkin, 'Excavations at Lachish 1973-1977', Tel Aviv 5 (1978) 10-25, fig. 3; see also Expedition 20 4 (1978) 20-21.

81. Tel Aviv 5 (1978) 24. 
The Obelisk Temple at Byblos possessed the characteristics of this temple type while the Beth shan Stratum V temple/82/ and the Tell el Farah building/83/ are a development of the earlier Egyptian influenced temples already mentioned in this group. Whether or not the northern temple of Beth Shan Stratum $\mathbf{v}$ belongs to this category is impossible to say with certainty because of the absence of any internal architectural details./84/ One building excavated in Stratum VIII Area DD at Megiddo must be mentioned as possibly belonging to this group/85/ as its plan is similar to the contemporary Late Bronze Age temples found at Lachish and Beth Shan Stratum VII. While some artefacts found in it did testify to Egyptian influences, the true function of this building which the excavators thought was a palace must for the present remain unresolved.

These temples do not relate to Solomon's temple and while they cannot indicate whether or not solomon's building was an Egyptian design as some have suggested,/86/ they do testify to the versatility of the Canaanite temple and the type of modification possible under foreign religious influence.

Longroom Temples (Fig. 6)

Mari, Temple of Dagan, Ur III. A. Parrot, Mari Capitale Fabuleuse (Paris: Payot, 1974) 100-108. Tell Chuera, E.B.. A. Moortgat, Tell Chuera III (Cologne: Westdeutscher Verlag, 1962) plan 2.

82. The exact plan of this temple is not certain as the S.E. corner was destroyed by a Roman reservoir. I am indebted to Frances James who is republishing the Beth Shan temples for her comments and information.

83. The cultic significance of this building is far from certain; see R. de Vaux, RB 64 (1957) 560.

84. A. Rowe, op. cit. 31-35.

85. G. Loud, op. cit., fig. 411. A. Harif, Levant 11 (1979) 164 has followed the excavators' assumption that this structure was part of the palace of area $A A$.

86. E. Renan, Histoire du Peuple d'Israël II (Paris: Lévy, 1889) 142-147; J. Garstang, op. cit. 382. 

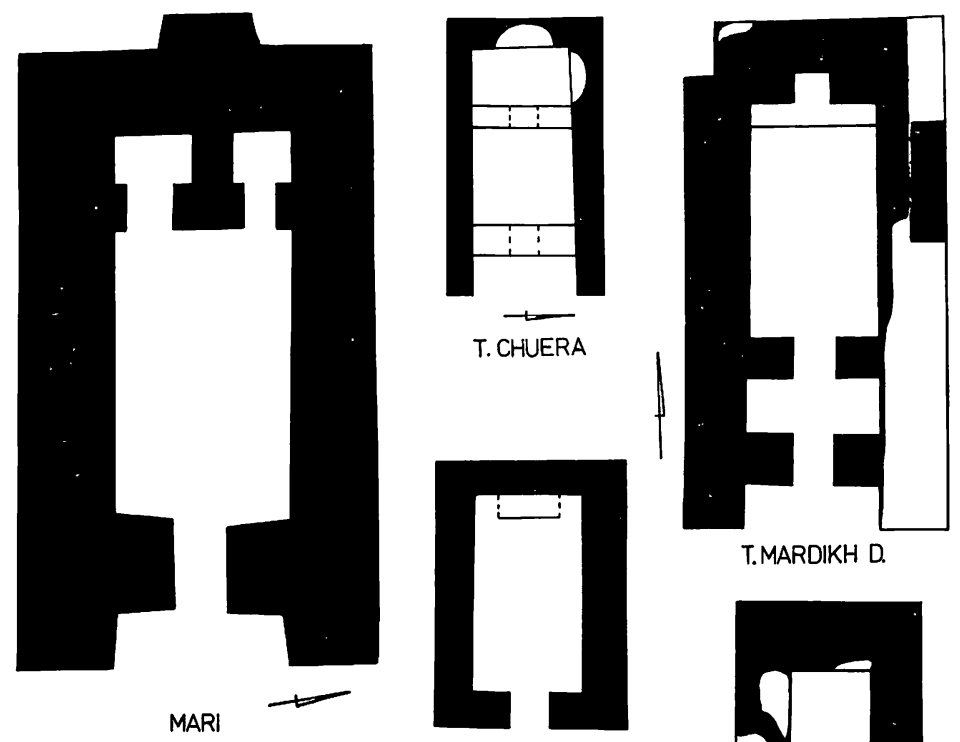

T.MARDIKH D.
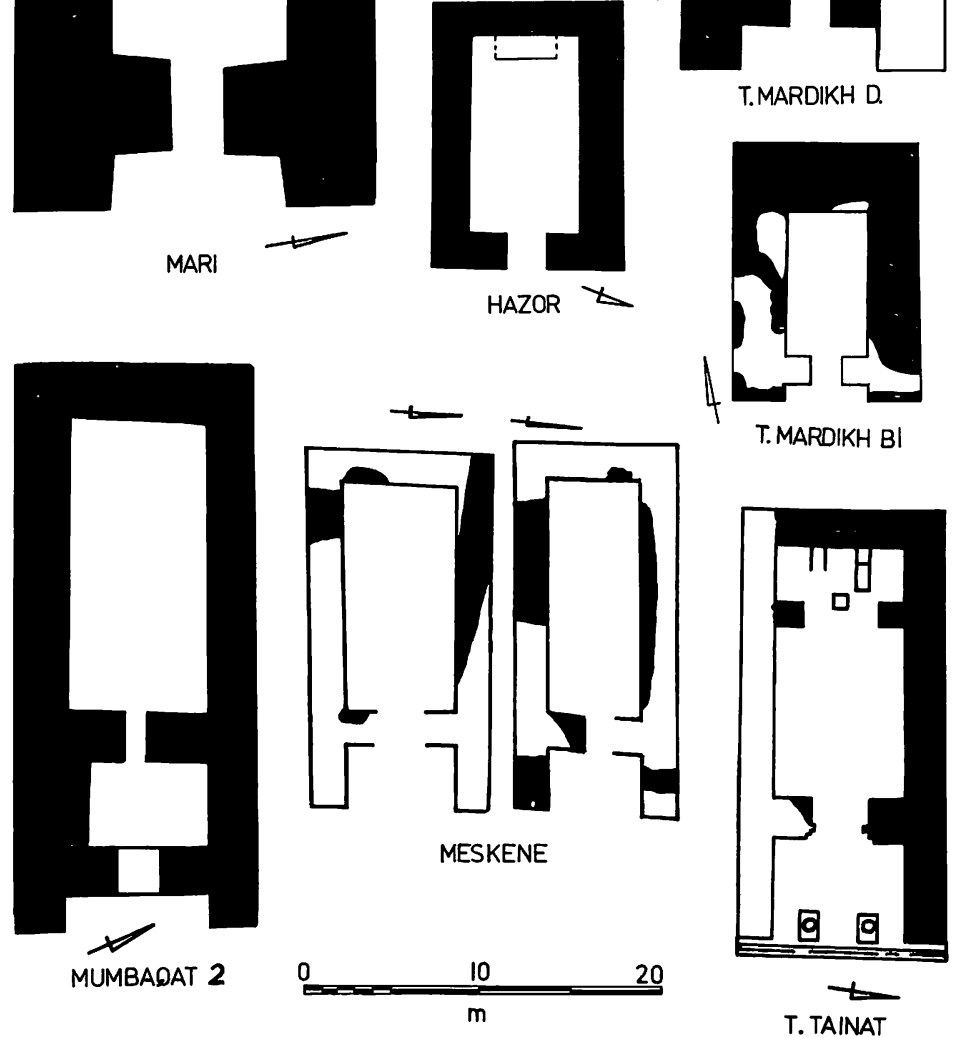

FIG. 6 Lor room Temples 
Hazor, Area A, M.B.-I.B.. Y. Yadin, Hazor

(London: OUP, 1972) 102-104, fig. 26.

Tell Mardikh, D, M.B.. P. Matthiae, 'Unité et Développement du Temple dans la Syrie du Bronze Moyen', RAI 20 (1975) 49, plan 3.

Tell Mardikh, B, M.B.. P. Matthiae, ibid. 63, plan 8.

Meskene. J. Margueron, 'Quatre campagnes de fouilles (1972-1974): un bilan provisoire', Syria 52 (1975) 62, fig. 3.

Mumbaqat, Temple 1. W. Orthmann, 'Mumbaqat 1974', MDOG 108 (1976) 26-29. (Not illustrated)

Mumbaqat, Temple 2. W. Orthmann, ibid. 29-32.

Tell Ta'yinat, Iron Age. R. C. Haines, Excavations in the Plain of Antioch II (OIP 95. Chicago, 1971) 53-55, pls. 100, 103.

Temples in which the main room has an axial length somewhat longer than its width are of course classified as Longroom temples. Solomon's temple had this design and so it is probable that the architectural tradition to which it was related is to be found amongst these buildings. The underlying principle of the Longroom design was the isolation of the god's image from the world. Most Longroom temples did not have courtyards in front of them, indicating that the worshippers may have entered the temple itself to perform their cultic duties. However it is unlikely that the relationship between the deity and its devotees was as intimate as A. L. Oppenheim has suggested it was in the Mesopotamian Longroom temple,/87/ as the image was probably located in the innermost enclosure, and even if it was visible from the main room it remained ultimately unapproachable.

As has been mentioned, the description of the debir in Solomon's temple implies that it was constructed entirely from materials such as cedar wood which would eventually perish without trace. It therefore remains quite possible that Longroom temples in which a small cella is not evident in the ground plan may in fact have possessed one built from wood and textiles.

87. A. L. Oppenheim, 'The Mesopotamian Temple', $B A$ Reader Vol. 1 (Missoula: Scholars Press, 1975) 161. 
A glance at the Longroom temple plans reveals that the numbers of rooms vary, although in all cases there was a room with proportions similar to the hêkāl of Solomon's temple. All except the Hazor temple had a porch while the temples at Mumbaqat and Tell Mardikh $D$ had anterooms. The temples at Tell Ta'yinat, Tell Chuera and Mari appear to have had small cellas at the rear of the temple while in the other temples this remains an open question.

None of the Longroom temples appear to have had stairways although the thickness of the walls in some instances signifies that they probably rose to a considerable height. The temples at Tell Mardikh, Mari and Tell $\mathrm{Ta}^{6}$ yinat are known to have been built on platforms which would have increased their elevation, while the temples at Tell Mardikh $\mathrm{D}$ and Meskene were sited in prominent locations giving them spectacular appearances and detaching them from the urban environment. P. Matthiae has already noted that the massive appearance of Temple $D$ at Tell Mardikh was an essential feature of this temple type. Longroom temples such as Temple $D$ were, he believes, not projections of religious or social organizations but were primarily the seat of the god; as such they were autonomous free standing structures which impressed by their massive bulk which was accentuated by their eminence and undecorated facade./88/

The Longroom temples at Mari, Tell Mardikh, Hazor and Tell $\mathrm{Ta}^{\text {Cyinat }}$ were associated with the palaces and therefore their appearances were a testimony not only to the power of the god but also of the monarch. The temples are in turn evidence for the religious tradition of the cities' political masters who were responsible for their construction.

One of the most uniform characteristics of these Longroom temples is the fact that with the exception of Tell Mardikh they all face east. Both the temples at Tell Mardikh face south. The siting of Temple $D$ on the western slope of the tell certainly would have made it impractical to have orientated the building in an eastwest direction. The temple was sited on a platform composed of an earlier religious building of Tell

Mardikh II and so its alignment was ostensibly determined by a previous cultic tradition at that location.

88. Loc. cit. 58 . 
Foundation deposits revealed that the Mari temple was dedicated to the God Dagan and was built by a governor of the Ur III period, Ishtup-ilum (c. 2100 BC). The temple is of particular interest because it has the approximate internal dimensions of the solomonic temple. The most obvious difference is the two small rooms at the rear of the temple. The excavator called these two rooms vestries ('sacristie') assuming that the deity's image rested on one of the three altars found in the main room. He may well be correct as far as the final phase of the temple is concerned but it is possible that originally the temple was dedicated to two gods, Dagan and his consort, whose images resided in the rooms at the rear of the temple. At Meskene, two Longroom temples were adjacent revealing that two gods were worshipped in that location and the temple at Tell Chuera also seems to have had provision for two gods./89/ A second departure from the Solomonic temple is the ziggurat which was adjacent to the temple of Dagan.

The origin of the design of the Longroom temple at Mari is not clear. The Ur III governors of Mari owed allegiance to the kings of $U r$ and this relationship is evident from such artistic display as the decoration of the Audience Chamber 132 in the palace which was completed in the Neo-Sumerian style of the Ur III period./90/ This dependence does not seem to exist in architecture, for while Ishtup-ilum built a Iongroom temple, the kings of lower Mesopotamia such as shu-sin were constructing traditional Babylonian Broadroom

89. At Tell Taya a bent axis temple was found with a pair of rooms at the rear; $c f$. H. E. W. Crawford, The Architecture of Iraq in the Third Millennium BC (Copenhagen: Akademisk Forlag, 1977) 49, fig. 5. The excavator of this building has no doubt that the two rooms were for a function other than housing the image of the deity. The Fosse Temple III also had two vestries; O. Tufnell, C. H. Inge, L. Harding, Lachish II The Fosse Temple (Iondon: OUP, 1940) pl. 168. These two temples are not directly related to the North Syrian Longroom temples.

90. A. Parrot, Mission Archéologique de Mari Vol. 2 Le Palais No. 2 (Paris: Geuthner, 1958) pl. 17 and E. 
temples./91/ The Audience Chamber in the palace at Mari was also a longroom and it is not until a subsequent period, possibly as late as Yasmah Adad, that a Broadroom audience hall was built in the palace./92/ Just as the Amorite and Assyrian kings at Mari and elsewhere tried to establish their legitimacy by copying Babylonian traditions in art, architecture and religion, so it seems the Babylonian governors of the Ur III period in Syria aimed to conform to local traditions in order to gain acceptance and be able to rule without unnecessary force. If this deduction is correct Longroom temples are an indigenous syrian building the origin of which is at present unknown.

While Temple D at Tell Mardikh was constructed at the beginning of the Middle Bronze Period soon after $2000 \mathrm{BC}$, the temples on the Upper Euphrates sites (cf. fig. 8) have not been chronologically fixed. The temple at Hazor was assigned to Middle Bronze II by $Y$. Yadin and it continued in use until the end of Late Bronze $I$.

The history of Longroom temples clearly continued in Assyria with the construction of such buildings at Assur as the Sin-Shamash temple/93/ during the reign of Assurnirari I (1516-1491 BC) and the Anu-Adad temple/94/ in the time of Assur-resh-ishi (1131-1114 BC) and Tiglath Pileser I (1113-1075 BC), Neo-Assyrian buildings such as the Nabu temples at Khorsabad/95/ and Nimrud,/96/ and the

91. H. Frankfort, S. Loyd, T. Jacobsen, The Gimilsin Temple and Palace of the Rulers at Tell Asmar (OIP 43. Chicago, 1940) 9-26, pls. 1-4.

92. A. Parrot, Mission Archéologique de Mari Vol. 2 Le Palais No. 1 (Paris: Geuthner, 1958) 104-110, room No. 64.

93. A. Hallex \& W. Andrae, Die Heiligtümer des Gottes Assur und der Sin-Šamaš-Tempel in Assur (Berlin: Mann, 1955) 82-92, pl. 16.

94. W. Andrae, Der Anu-Adad-Tempel in Assur (Leipzig: J. C. Hinrichs, 1909) .

95. G. Loud and C. B. Altman, Khorsabad II (OIP 40. Chicago, 1938) 56-64, pls. 70, 71, 79.

96. M. E. L. Mallowan, Nimrud and its Remains (London: Collins, 1966) 231-288, fig. 194. 
temple of Adad-nirari III at Tell Rimah./97/ Most of these buildings were double temples continuing the tradition of the Mari and Meskene temples. The Nabu temples possessed an ambulatory surrounding the cella, a feature which may be akin to the side rooms which surrounded solomon's temple. The principle behind the ambulatory was probably not practical but rather theological as it served to separate the god or holy place from the world even more than was already the case. The insulating rooms around the main room of the temple are not found in any of the Levantine Longroom temples of the second millennium $\mathrm{BC}$ which were isolated by their location. Busink has suggested, however, that the side rooms of Solomon's temple originated from a casemate construction common in Solomonic fortifications./98/

The tradition of Longroom temples in northern Syria was quite distinct. Unlike Assyxian Longroom temples they were invariably prominent freestanding buildings composed of no more rooms than were absolutely necessary to lodge the god's image for the purpose of receiving homage. There were no facilities for the priesthood, so that the entire establishment emphasized the deity's transcendence./99/ The tradition of Iongroom temples appears to have continued in northern Syria and is evidenced by the ninth century BC temple at Tell Ta'yinat. Even if this temple was constructed under Assyrian influence,/100/ the characteristic autonomy and eastward orientation of the previous Levantine Longroom temples was preserved. Kuschke notes that the Longroom temple design continues in northern Syria until the Roman Period and lists thirty-seven examples, thirty-four of which faced eastwards./101/

97. David Oates, 'The Excavations at Tell Al Rimah, 1967', Iraq 30 (1968) 122-133, pl. 33.

98. Op. cit. 611 .

99. For further discussion of supposed Assyrian influences on the Jerusalem temple, see Busink, op. cit. 580-581.

100. H. Frankfort, op. cit. 175.

101. See 0. Keel, The Symbolism of the Biblical World (New York: Seabury, 1978) 161, figs. 219, 220. 
Migdol Temples (Fig. 7)

Shechem. G. E. Wright, Shechem. The Biography of a Biblical City (London: Duckworth, 1965) 80-102. Megiddo. G. Loud, Megiddo II (OIP 42. Chicago, 1948) 102-105, fig. 247.

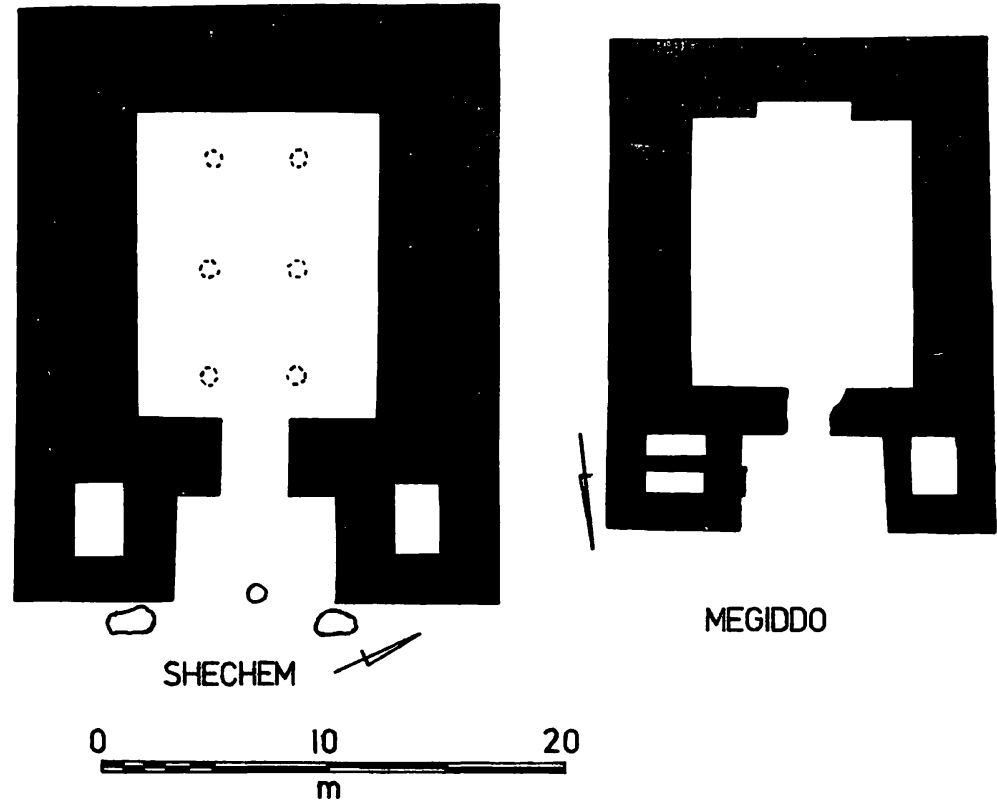

FIG. 7 Migdol Temples

During the 1920's, E. Sellin excavated a large building at Shechem which he believed was a temple. Further excavations by G. E. Wright in the 1950's seemed to confirm Sellin's identification when an altar in front of the building was unearthed together with two column bases flanking its entrance. A similar building was found at Megiddo and together with the Shechem structure this seems to testify to the existence of a definite class 
of temple in Palestine./102/ The walls of both buildings are a few metres thick indicating that they may have risen to some considerable height. It is not impossible that the walls of these temples were of casemate construction thus enabling the sanctuary to be surrounded with side chambers as was the case in Solomon's building.

The two temples may be classified as Longroom, but clearly they are proportionately broader than all the Longroom temples previously discussed. The length to width ratio of the main room is between that of the Longroom and the Levantine Broadroom and they share a number of features with the Levantine Broadroom temples. They have staircases for access to the roof. The Shechem and maybe the Megiddo temple also had free standing columns flanking the entrance and a courtyard altar. On the other hand, in common with the Longroom temples, both were built on platforms and were massive structures. The Shechem temple also faced the east, as do most of the Longroom temples, while the Megiddo temple is aligned north/south.

Both the Megiddo and Shechem temples were possibly built towards the end of the Middle Bronze Age, anc Wright believed that the Shechem temple was in use until the eleventh century BC./103/ This enabled him to identify

102. B. Mazar, 'The Middle Bronze Age in Palestine', IEJ 18 (1968) 93; but G. R. H. Wright, 'Temples of Shechem', ZAW 80 (1968) 22, is less certain.

103. The dating of the Megiddo building is uncertain. Kenyon's redating of the Megiddo strata makes it a 14th century construction: $K$. M. Kenyon, 'The Middle and Late Bronze Age Strata at Megiddo', Levant 1 (1969) 25-60. C. Epstein however assigned its construction to an earlier stratum (XII): 'An Interpretation of the Megiddo sacred area during Middle Bronze II', IEJ 15 (1965) 217. I. Dunayevsky, A. Kempinski, 'The Megiddo Temples', zDPV 89 (1973) 182, argue that the Migdol temples were built during MB IIC but that the towers of the Megiddo temple were a later addition. 
it with the tower (migdol) and temple of El Berith and Baal Berith (Jdg. 9:46-49). If the shechem temple was in fact the one destroyed by Abimelech, there is direct contact with the Israelites, albeit a century before the time of Solomon.

It was postulated by schult that the debir of Solomon's temple was a wooden cubicle which could easily have been added to the Migdol temple making it similar to Solomon's temple and that Solomon's building itself, like the Migdol temples, consisted of a single room./104/ Noth agreed that the only acceptable parallels with Solomon's temple are the Migdol temples of Shechem and Megiddo. /105/ However, the Solomonic debir was a fixture which occupied the entire width of the temple and a similar structure occupying the entire width of the Migdol temples would have been much larger than the debir of Solomon's temple and left a small main room of Broadroom proportions in front of it.

The debir aside, the Shechem and Megiddo temples do not greatly resemble the temple of Solomon. The proportions are quite different and they had towers, staircases to the roof and thick walls (unless they were casemate), none of which are included in the description of solomon's temple.

\section{CONCLUSIONS}

The known Levantine Broadroom temples were confined to the coastal areas of the Levant and to Palestine where, it appears, they represent a fairly uniform religious tradition./106/ While it may be true that ethnically, politically and linguistically Ras Shamra was largely independent of the southern Levant,/107/ this certainly

104. H. Schult, 'Der Debir im Salomonischen Tempel', ZDPV 80 (1964) 54 .

105. M. Noth, Könige, Biblischer Kommentar, Altes Testament IX (Neukirchen Vluyn, 1968) 105.

106. P. Matthiae, Ioc. cit. 68.

107. A. F. Rainey, 'The Kingdom of Ugarit', $B A$ Reader Vol 3 (New York, 1970) 79. 
does not appear to be the case with regard to religion, if temple plan is an indication of religion. It follows that if the religious tradition of the south can be called Canaanite, then so too can the religion of Ras Shamra. The temples at Ras Shamra were located some distance from the palace/108/ and they would have had considerable religious independence so that the religion of the populace could have continued in what was probably a Canaanite tradition.

The second millennium BC Longroom temples form a tradition geographically distinct from the Levantine Broadroom temples. The two traditions meet in Palestine at Hazor and it is possible that the Migdol temples represent a fusion of the two traditions.

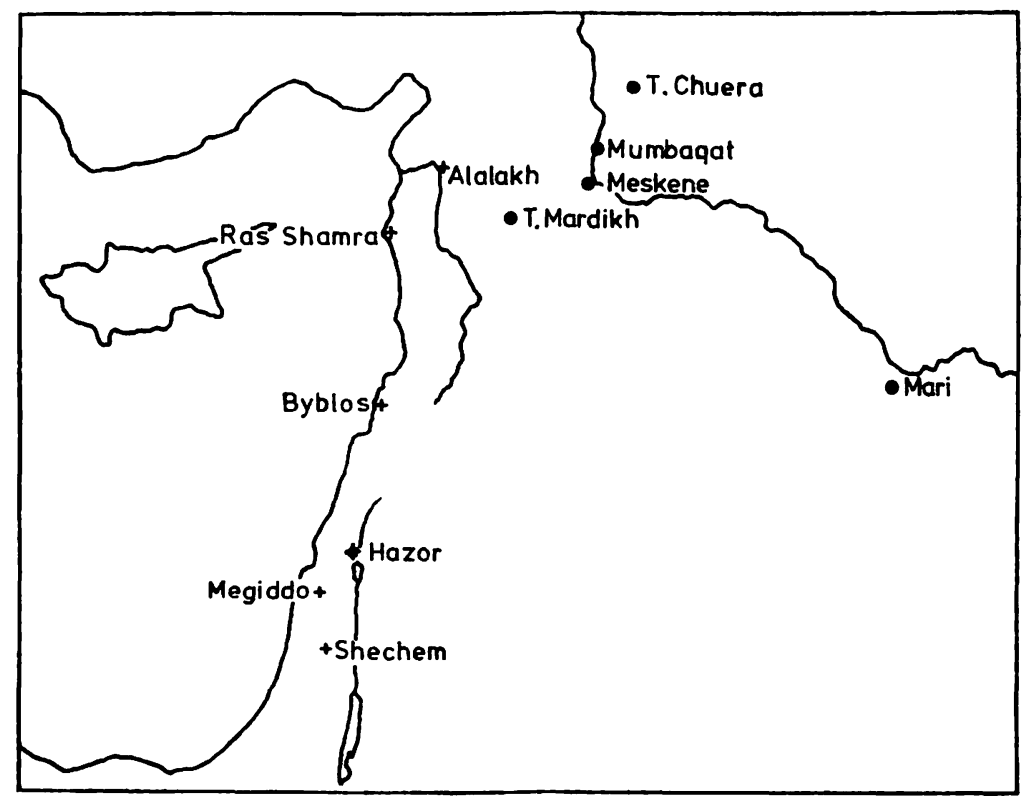

FIG. 8 A distribution map of Longroom Temples (indicated by dots) and of Levantine Broadroom Temples (indicated by crosses)

108. J. Margueron, 'Ras Shamra 1975 et 1976. Rapport Préliminaire sur les Campagnes d'automne', Syria 54 (1977) 154, fig. 1. 
One theory postulates that the Broadroom temples of Early Bronze Age Palestine were progressively elongated into such temples as the Area $\mathrm{H}$ temple at Hazor and ultimately became the fine long room building of Solomon's temple./109/ However, from the Middle Bronze Age there were in the Levant distinct traditions of Iongroom and modified Broadroom temples. Solomon's temple building does not combine features from Levantine Broadroom and the Longroom and instead definitely belongs to the Longroom tradition of northern Syria; like them it faced eastward, was free standing, and had a main room of similar proportions. The side rooms, if that is what they were, of Solomon's temple are a notable addition not observed in any Levantine temple tradition of the second millennium BC. The debîr is definitely found in some of the Longroom temples and is to some extent a feature of the Levantine Broadroom temples modified under Egyptian influence./110/ The tabernacle had a partitioned room to contain the ark so that the $d$ ebir may have been an

Israelite addition to the Longroom temple./111/ Even if this was true, the fact remains that the Longroom design was suitable for such an alteration and the architectural principles were compatible with the modification.

Th. A. Busink's conclusion that solomon's temple was an Israelite invention/112/ must now be modified because it is clear that as far as the building itself was concerned there was a comparable tradition of temple design in the Levant during the second millennium BC. How these principles of design were transmitted to King solomon is at present unclear, and, while it is possible that further excavations may reveal the missing links, it is

109. See discussion by Th. Busink, op. cit. 591.

110. A. Parrot, op. cit. 55, uses the image of darkness within the debîr, $1 \mathrm{Ki} .8: 12$, as evidence for Egyptian influence in the Solomonic debir. For a discussion of theories see 0 . Keel, op. cit. 161-163.

111. E. W. Heaton, Solomon's New Men (Iondon: Thames and Hudson, 1974) 18. Th. A. Busink, op. cit. 609, argues that the $d$ ebir was an incorporation of the entire tabernacle into the temple of solomon.

112. Op. cit. 617 . 
also possible that Solomon revived an archaic Israelite tradition observed to some extent in the tabernacle and possibly known to even more distant ancestors who were acquainted with the Longroom temples of northern Syria and found them architecturally appropriate for the cod they worshipped.

The courtyard facilities of Solomon's temple and its decoration, such as the free standing columns, were common in the Levantine Broadroom temples and a number of cultic shrines. These temples were projections of a definite social and religious organization of which they were an integral part. Both priests and people, merchants and craftsmen had responsibilities to be performed within the temple complex, which was constructed to provide them with the necessary facilities.

While Solomon's temple had certain equipment for the religious observarce of the populace and priesthood, it was also the place where the name of Yahweh dwelt and therefore the temple building itself was an expression of his character. To this end the Longroom temple design was considered an appropriate structure in which to house the objects that were ancient Israel's sacred heritage. The temple was to be visible from a distance and was probably built on a platform like most Longroom temples in the Levant and according to the description of Ezekiel. The building aimed to impress by its size and prominence and so, in contrast to the Levantine Broadroom temples, it was free standing and was therefore architecturally autonomous and non-urban in character. The reconstruction offered by Albright and wright is therefore to be preferred to that suggested by Busink because by making the front facade the full height of the building it displayed greater mass. The general isolation from other structures signified a separation from the city which not only illustrated Yahweh's transcendence but also his non-dependence on the inhabitants of Jerusalem and his universal sovereignty (1 Ki. 8:23-55). 


\section{APPENDIX}

A Possible Solomonic Longroom Temple at Megiddo (Fig. 9)

It has been suggested throughout this paper that buildings excavated in Area $A A$ and coordinates $K-7$ at Megiddo were possibly temples. Already mentioned is a structure associated with the Stratum VIII palace which appeared to be a Levantine Broadroom temple,/113/ while in Stratum VII A there was a three-roomed building./114/ Although the remains of these buildings were bereft of cultic furniture, a third building belonging to stratum VA certainly was not. A cluster of altars, incense stands, basins, jugs, bottles and a model shrine were found stowed in the south-west corner of the courtyard of the building, which was quite possibly a temple./115/
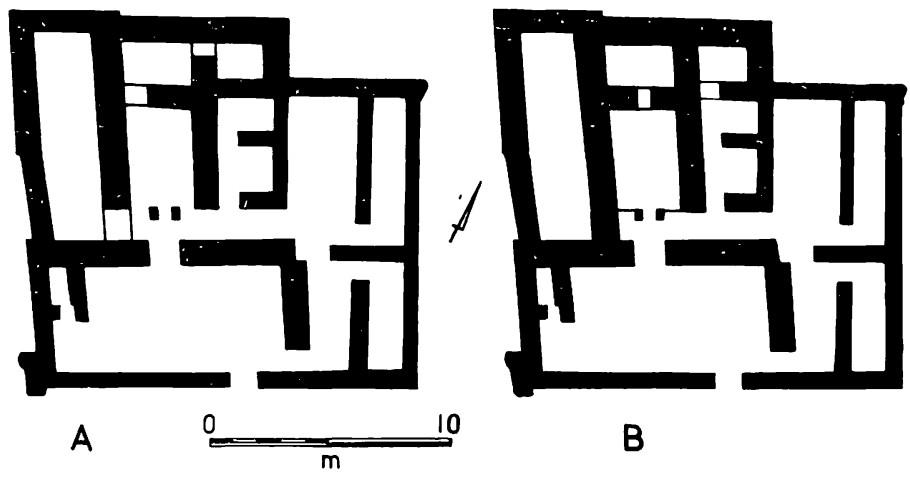

FIG. 9 A. The published reconstruction of the Megiddo building in $A r e a ~ A A$, square $K 7$, Stratum VA

B. The suggested alternative reconstruction

113. See above p. 122 .

114. See above pp. 113-115.

115. G. Loud, op. cit., figs. $101,102$. 
The published restored plan of the building does not appear to have any distinguishing religious features (fig. 9A)./116/ It is said of its architectural remains that, 'the absence of thresholds and the fact that the tops of the walls are found in many cases at floor level, so that most door locations are lost, also makes positive restoration difficult'./117/ The area plan reveals that the door locations, which are in fact unknown, are precisely those which make the plan unintelligible./118/

The plan suggested in figure 9B produces three parallel ranges of rooms. The central sequence of chambers is arranged symmetrically about the longitudinal axis so that there is a long room which leads to a second smaller room. Just inside the entrance of the longroom were two pillars which may have been free standing although it is more likely they formed the door posts of a partition which divided the longroom in two. Even if the pillars were not part of a dividing wall, they make an effective partition themselves. The resulting plan is notably similar to the temple of solomon, although on a smaller scale, having a porch, a main longroom and a much smaller holy room. The similarity is made more pronounced by the ranges of rooms along each side of the sanctuary which may correspond to the side chambers which surrounded Solomon's temple. This temple however was not free standing and may not have had the same courtyard facilities as the Jerusalem temple, but it does represent the closest architectural parallel excavated to the present in Palestine.

Stratum VA at Megiddo is not indisputably dated and in fact it is not always certain that buildings or artefacts did actually belong to the stratum to which the excavators attributed them./119/ However it seems probable that the Megiddo Stratum VA was contemporary

116. Ibid., fig. 100 .

117. Ibid. 45.

118. Ibid., fig. 388.

119. K. Kenyon, Archaeology in the Holy Land, 246-249. G. E. Wright, 'The Discoveries at Megiddo 19351939', The Biblical Archaeologist Reader Vol. 2 (Ann Arbor: Scholars Press, 1975) 236, 237. 
with King Solomon and if the aforementioned building was a temple, the Jerusalem temple plan was not unique in Palestine. Unfortunately there is no way of conclusively identifying the true function of the Megiddo building now that it has been excavated. 